\title{
Assessing the Effects of Oil Spill on Clean-up Workers and Communities' Participation in Imo State Nigeria
}

\author{
Alphonsus O. Isidiho ${ }^{1}$, Nik Ahmad Sufian Burhan ${ }^{1 *}$, Mohammad Shatar Sabran ${ }^{2}$, \\ Mohd Ibrani Shahrimin Adam Assim ${ }^{1} \&$ Ahmad Tarmizi Talib ${ }^{3}$ \\ ${ }^{I}$ Department of Social and Development Sciences, Faculty of Human Ecology, \\ Universiti Putra Malaysia \\ ${ }^{2}$ Universiti Pendidikan Sultan Idris, Tanjong Malim, Perak, Malaysia \\ ${ }^{3}$ Department of Politics and Government, Faculty of Human Ecology, \\ Universiti Putra Malaysia \\ Email: nikahmadsufian@upm.edu.my
}

DOI: https://doi.org/10.37134/jcit.vol10.sp.2.2020

Cite this paper (APA): O. Isidiho, A., Burhan, N. A. S., Sabran, M. S., Adam Assim, M. I. S., \& Talib, A. T. (2020). Assessing the Effects of Oil Spill on Clean-up Workers and Communities' Participation in Imo State Nigeria. Journal of Contemporary Issues and Thought, 10, 10-24. https://doi.org/10.37134/jcit.vol10.sp.2.2020

\begin{abstract}
The problems associated with oil spill clean-up has been of burden to all oil spill stakeholders all over the world and the method of clean-up depends on the type of spill, the volume of spill, the location and weather at the time of clean-up. Generally, while the clean-up of oil spill on the sea involves the use of standard oil boom, foxtail skimmer and dispersion system mounted on an airplane, spill on land can be cleaned with high-pressure system, scooping, and in-situ burning. In Imo State, the clean-up was through in-situ burning, scooping and burying the oil. The communities participated in the clean-up as voluntary services and sometimes for financial gains. The study utilized mixed methods and a total of 376 correctly filled and returned out of 400 administered questionnaires were used and 13 interviews were conducted for this research. Purposive sampling method was utilized for the qualitative as it gave the researcher the opportunity to select informants with deep knowledge and experience coupled with willingness to release the authentic data required for the analysis of the study. The findings show that communities in Ohaji/Egbema and Oguta in Imo state Nigeria actively participated in oil spill clean-ups in their localities whenever there was spill and at the end of it, they suffered great psychological, health and other socio-economic impacts.
\end{abstract}

Keywords: Communities; Oil Spill Clean-Up; Participation; Impacts; Stakeholders

\section{Introduction}

Oil spillage in recent time has been a serious problem in areas where oil drilling is prominent and also at the various sea routes through which ships sail and crude oil are transported through oil vessels. The severe impacts of spillages have alerted various governments, organizations, private bodies and individuals as well as the stakeholders in the oil industries on the need to control the rate of spillages if it cannot be stopped. Studies are continually investigating previous and recent oils pillages all over the world especially on their impacts as oil spill impacts lingers for long period even up to 50 years despite the clean-up (United Nations Environment Programme [UNEP], 2011). Notable oil spills include the Gulf of Mexico spill, Venezuela, Alaska in California, the Gulf war spill, the spill in Netherlands, the spills of New Zealand, Turkey, Guimaras in Philippine, Hebei Spirit Oil Spill in South Korea, etc. 
This study focused on oil spill in Ohaji/Egbema and Oguta communities in Imo State Nigeria. The theoretical framework of the study utilized the stakeholders theory and the crisis management theory, hence stakeholders in oil spill include the government, the media, the oil industry, the fishermen and crop farmers, the tourist-driven communities, the touristdriven businesses, the tourist themselves, the oil spill clean-up workers, the environmental activist and the environment itself. This list summarizes the internal and external stakeholders in an oil spill situation, an explanation of the wide range of people impacted by the spill.

Oil spill is the uncontrolled release of crude oil into the environment (Rim-Rukeh, 2015). When oil of any type is released into the natural environment, the result is termed an "Oil Spill" (Sholeye et al., 2012). Similarly, Etkin (2001) gave a broader definition as he defined oil spill as "discrete event in which oil is discharged through neglect, by accident, or with intent over a relatively short time. It does not include an event in which oil leaks slowly over a long period of time, nor does it include operational spillages allowed by international or national regulations or that occur over a relatively long period of time, even if those discharges violate pollution regulations". Oil spills come from tankers, pipelines, oil wells, storage tanks and vessels cleaning out tanks. The type of spill, the quantity spilled, the location, the weather and the response determine the subsequent impact in the location or community. It becomes arguable by the researcher that the socio-cultural and economic conditions of the people of Ohaji/Egbema, Oguta and the Niger Delta region of Nigeria intercalate the purported destructive tendencies on the oil pipeline and this is not prevalent in other locations of the world.

\section{Review of literature}

The Exxon Valdez oil spill into the waters of Prince William Sounds Alaska was estimated to 11 million gallons (260,000 barrels) on 24 March 1989 accident (Palinkas et al.,1993). The Ixtoc 1 oil spill of June 3, 1979 by a Mexican oil company PEMEX was the largest offshore oil spill incident before the Deepwater Horizon spill of 2010. In the Ixtoc spill, about 475,000 metric tons of crude oil was spilled. Likewise, Christopherson (1992), argued the collision of the Exxon Veldez caused 240,500 barrels (10.9 million gallons) out of the 53 million gallons of oil to leak into the water and this affected the whole range of the coastlines covering about 1,100 miles in Alaska.

Pipeline leakage is one of the causative sources of spillages as reports have it that on July 26, 2010, a pipeline released approximately 800,000 gallons of crude oil into Michigan's Talmadge Creek, a waterway that flows into the Kalamazoo River. Moreover, on July 1, 2011, an ExxonMobil pipeline ruptured and released oil into the Yellow stone River near Billings, Montana and discharged an estimated 42,000 gallons (Ramseur, 2012). In a study, Steiner (2010) compared the oil spill in the Gulf of Mexico and Nigeria, estimated 4.1 million barrels spilled in the Gulf while about 9 to 11 million barrels spilled in the Niger Delta Region for the over 50 years of oil exploration with its adverse harmful effects and emission of flaring gas into the atmosphere. Whereas the Gulf spill continues to be cleaned up, and receive enough funding and government attention, that of the Niger Delta Region were left without the required attention.

Oil spill is a regular occurrence in the Niger Delta recording about ten times a week and these spills are traceable to oil installations (pipelines, flowlines, well-heads, flow stations, 
storage tanks etc.) (Kate, 2011). However, in recent time some of the spillages in the Nigerian environment are allegedly traceable to sabotage and illegal bunkering activities (Adelana et al., 2011). Amnesty International (2013) stated "oil spills in the Niger Delta are caused by corrosion, poor maintenance of oil infrastructure, equipment failure, sabotage and theft of oil". The Nigerian National Oil Spill Detection and Response Agency (NOSDRA), wrote that oil companies reported 2,054 cases of oil spill incidents (spills of more than one barrel) between June 2006 and June 2010, these figures have been arguably posited to be a "protective" figure and below the actual.

Amnesty International Head of Business and Human Rights; Audrey Gaughran, summarized the oil spill impact in the Niger Delta region thus: "People living in the Niger Delta have to drink, cook with and wash in polluted water. They eat fish contaminated with oil and other toxins-if they are lucky enough to be able to find fish still. The land they farm on is being destroyed. After oils pills, the air they breathe smells of oil, gas and other pollutants. People complain of breathing problems and skin lesions - and yet neither the government nor the oil companies monitor the human impacts of oil pollution" (Kate, 2011).

The effects of oil spill include, the beauty or the aesthetics of the ecology is distorted and destroyed, gross biological harm, physiological impacts on the biota (both plants and animals) and a lot of ecological changes, cellular, organismic and ecosystems also witness great changes, the toxic substances affect organism while the water pollution affects tourism and human uses of the water including using it as means of transportation and trade (RimRukeh, 2015). The Nakhodka tanker oil spill in Japan showed that the clean-up participants and local residents initially suffered back pain and leg pain, headache, and symptoms of eyes and throat (Morita et al., 1999). Similarly, the Hebei spill studies indicated many health impacts (Zock et al., 2007; Jung et al., 2017; Ha et al., 2012; Choi et al., 2016; Gwack et al., 2012; Janjua et al., 2006; Yim et al., 2012; Hong et al., 2014; Cheong et al., 2011). Likewise, much harm caused by the dispersants leads to the release of toxic particles which harm the planktons and marine organisms (Whitehead et al., 2012). Air pollution by oil spill affects respiration and other health hazards in both humans and non-human organisms causing irritations, cough, rashes and eye problems (Nriagu, 2011; Egwu, 2012; Ajugwo, 2013; Adelana et al., 2011).

The impact of oil spill on land where humans reside differs from the impact when the spill is on the high sea, such spills on high sea includes the Deepwater Horizon Gulf spill in Mexico (2010), the Ixtoc1spillin Mexico (1979), Exxon Valdex oil spill in Alaska California (1989), Korea oil spill (2007), Odyssey spill in Nova Scotia Canada (1988), Prestige Tanker oil spill in Spain (2002), Funiwa 5 spill in Nigeria (1980), Nagasaki Spirit at Malacca Strait Malaysia (1992) etc. Usually, such spills impact on the coastlines, the aquatics in the water, environment, and businesses including the tourism. However, spills on both water and land have greater impacts and the Niger Delta region of Nigeria is a good example where such spills occur and that is why the impacts are so pathetic and rare occurrence. The residents of the Niger Delta smell oil, eat oil and very sick, no good drinking water, no social amenities, loss of means of livelihood as they are traditionally farmers. The land and farms covered with oil, the water with oil slick, complete disarray and occupational displacement. All these definitely have multiplier effects on health, income and other socio-economic variables. These impacts are in congruence with similar studies in other locations where the spill occurred (Ha et al., 2012; Kwok et al., 2014). 
Table1.1: Oil spillage, volume and causes from 2005 to 2010 in the Niger Delta Region of Nigeria

\begin{tabular}{cccl}
\hline Year & No. of spills & Vol. of spills/barrels & \multicolumn{1}{c}{ Major causes } \\
\hline 2005 & 180 & 10,000 & Sabotage $-95 \%$ \\
2006 & 170 & 20,000 & Sabotage and operational $50 \%$ each \\
2007 & 250 & 30,000 & Operational $70 \%$ sabotage $30 \%$ \\
2008 & 170 & 100,000 & Operational and sabotage $50 \%$ each \\
2009 & 150 & 110,000 & Sabotage $90 \%$ and operational $10 \%$ \\
2010 & 190 & 28,000 & Sabotage $80 \%$ and operational $20 \%$ \\
\hline
\end{tabular}

Source: Amnesty International (2011)

Table1.2: Potential sources of Oil Spills

\begin{tabular}{lc}
\hline Sabotage / Bunkering & $36 \%$ \\
Engineering & $0.50 \%$ \\
Human Error & $2 \%$ \\
Corrosion & $36 \%$ \\
Equipment Failure & $6 \%$ \\
Others & $2.50 \%$ \\
\hline Source: Adelana et al. (2011) &
\end{tabular}

Figure1.1: Causes of oil spill

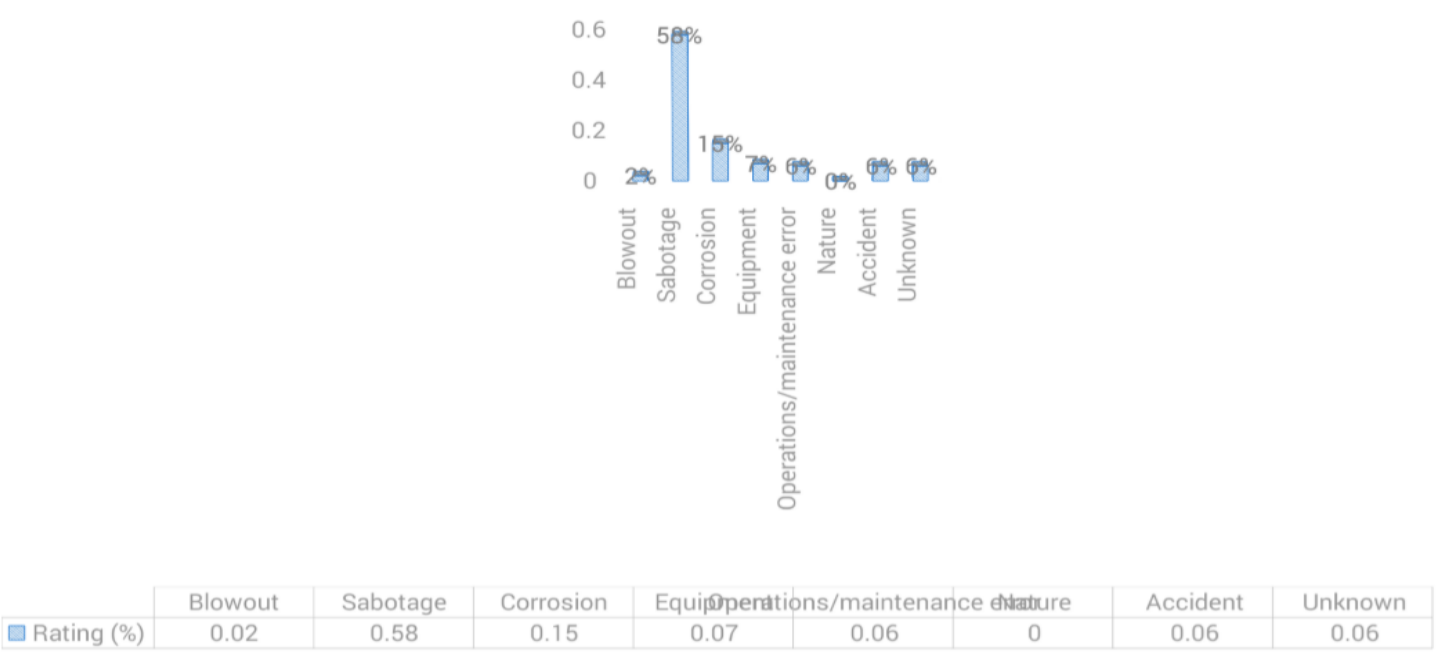

\section{Response and clean-up operations in event of oil spillage}

Researches have shown that early response to oil spillage has reduced the impacts (Balena, 2015; Gutierrez, 2011; Hazen et al., 2010; National Oceanographic and Atmospheric Administration [NOAA], 2010; Etkin et al., 2005; White \& Molloy, 2003; Klemas \& Blazauskas, 2014). At the height of response operation of Exxon Valdez spill, more than "11,000 personnel, 1,400 vessels, and 85 aircrafts" participated in the clean-up exercise (Christoperson, 1992). Gulf of Mexico oil spill in the United States involved more than 100,000 persons, including professionals and community workers participated in the cleanup operations (Zock et al., 2011). It should be noted that the type of clean-up used depends greatly on oil type, the concentration of the oils lick on the surface of the water, the environmental and weather conditions (Muizis, 2013; Biello, 2010). Clean-up workers who 
participated in the Prestige oil spill were found "risk of having persistent respiratory symptoms (reported both at baseline and follow-up) increased with the degree of exposure: RR ratio 1.7 (95\% CI 0.9to 3.1) and 3.3 (95\% CI 1.8 to 6.2) for moderately and highly exposed, respectively, when compared with those without any symptoms, which may result in respiratory symptoms that persist up to 5 years after exposure" (Zock et al., 2011).

Similarly, various authors commented on the type of response and clean-up during and after oil spill and the health impacts depending on the type of spill and density of oil, the location of spill, the volume of spill and the weather as at the time of spill (Turan, 2009; Di Natale, 2010; Betinis, 2010; Abbriano et al., 2011; Jones, 2011; Pigrau, 2012; Eykelbosh, 2014; Solomon, 2010).

One of the most terrible oil pipeline disasters happened in Warri Niger Delta Nigeria in October 1998, where over 700 deaths were recorded (Epstein et al., 2002). Inadequate response measures, was contributary to the high death in the accident as the fuel ignited and engulfed the whole people causing the death of over 700 people as the explosion and flames were very high and could be seen from far places as it was as high as 20 meters high (Epstein et al., 2002). The Deep-water spill in Mexico occurred on the sea and hence the clean-up operations would not be the same as the one that occurred on land. The accident of the Hong Kong tanker Hebei Spirit on December 7th, 2007 near the shore of Taean Korea, where over 12,547 kl (kilolitre) of spilled into the sea attracted a different clean-up operation than the Deep-water spill.

Over one million volunteers participated in the clean-up operations for as long as six months interval. The study of the health impacts on the participants on the clean-up operation of the Deepwater Horizon spill in Mexico concluded that adverse health outcomes were discovered on these participants. The development of alterations in hematological profile and liver function was part of the risk expected by people who participated in the clean-up exercise (D'Andrea \& Reddy, 2013). Also, Lee et al., (2016) conducted a study on the impact of the Deepwater Horizon oil spill on depressive health symptoms among residents of Mississippi Coast and related lifestyle. And their findings showed the exposure of the clean-up workers and residents resulted in great depressive symptoms which also disrupted the gulf/ocean-related lifestyle.

The health impact of oil spill on the clean-up workers and other humans closer to the spill location were investigated in various researches and findings showed a lot of negative health impacts (Lee et al., 2016; Stanbury et al., 2010; Sholeye et al., 2012; D' Andrea \& Reddy, 2013; Shultz et al., 2014; Gill et al., 2012; Jung et al., 2017; Ha et al., 2012; Choi et al., 2016).

Peres et al., (2016) found short- and long-term physical, mental, and community health effects on the southern Louisiana women exposed to the oil spill and discovered that they were associated with an increase in self-reported physical health outcomes. In the same vein, Rung et al., (2016), discovered that Southern Louisiana women who were exposed to the oil spill had revealed high rates of poor mental health outcomes. Likewise, Averett (2016) found that women's mental health and possibilities of domestic conflict were part of the effects of the Deepwater Horizon oil spill in 2010, while 13\% showed symptoms of severe mental distress, $16 \%$ reported more fights with their partners and $11 \%$ acknowledged higher intensity to fight. However, this study could not take prior records of these women behaviours before their exposure to the oil spill. Psychosocial impact of the Exxon Valdez Spill includes disruptions to daily and family life, as well as increased mental stress (Gill, 2007; Gill \& Picou, 1997; 1998; 2001; Picou \& Arata, 1997; Picou \& Gill, 1996; Ritchie et al., 
2012; Gill et al., 2014) while the negative health impacts on clean-up workers were explained by D'Andrea \& Kesava (2018).

Similarly, the Hebei spirit Korea clean-up operations involved both "military personnel and governmental employees, professional clean-up workers, members from civic groups, schools and universities, companies, communities, and families and individuals" (Ha et al., 2012). The findings of the study show that the increase in physical symptoms including visual disturbance, nasal and bronchus irritation, headaches, heart palpitations, fatigue and fever, memory and cognitive disturbance, and abdominal pain were some of the reports of the volunteer workers at the clean-up operation who worked longer (Ha et al., 2012). It is of note that these symptoms and effects were noticed with in the short-term period and for a longer time period the results may be more serious if not effectively handled. Using the multiple logistic regression analysis that was adjusted for age and gender, Ha et al. (2012), examined the effects of the oil spill on 1,362 children attending elementary close to the oil spill location. The result shows the "significantly higher symptom risk of depression compared to those with the farthest distance".

The psychological health of participants in the clean-up operation of the Hebei Spirit oil spill in South Korea was examined using the post-traumatic stress (PTS), depression, suicidal ideation and anxiety through questionnaire administered on 993 residents of the spill location. Their findings were that there were higher symptoms of depression, suicidal ideation and anxiety especially in female, older, less educated and low-income earners, those in fishery and coastal area related businesses and residents within the spill area (Choi et al., 2015). The psychological stress experienced by some community members in oil spill could be imagined in the words of Choi et al., (2015) saying that " 4 residents from the affected communities committed suicide from January 2008 to February 2010". Similarly, Psychosocial impact of the Exxon Valdez Spill includes disruptions to daily and family life, as well as increased mental stress (Gill \& Picou, 2001; Gill, \& Picou, 1998; Gill, 1997; Gill et al., 2012; 2014; Picou \& Gill, 1996; 1997; Ritchie et al., 2012; Hansel et al., 2015). The Psychological impacts on the clean-up workers and communities at large in Ohaji/Egbema and Oguta communities were examined using the Impact Event Scale (IES) by Horowitz et al., (1979). The findings showed the residents and those who participated in the clean-up suffered various levels of psychological disorder. These studies strongly emphasize the negative and similar health impacts the spill has on clean-up workers in all locations including the location of study.

\section{Common approach for Oil spill clean-up}

Study has shown that oil sorption capacity of unmodified empty fruit bunch fibre efficiency is influenced by oil volume, time, and fibre weight for engine oil clean-up (Idris et al., 2014). Similarly, review on the various oil spill absorbents materials such as natural organics or bents, inorganics or bents and synthetics or bents and their effectiveness as a clean-up apparatus can be good alternative methods of oil clean-up. Some of the tested "organic sorbents include rice straw, corn cob, wood fiber, sawdust, cotton fiber, kapok fiber, wool fiber, kenaf fiber, milkweed, rice husk, coconut husk, cattail fibre, hay, feathers and bagasse" (Asadpour et al., 2013). In a similar study on the oil spill recovery and clean-up using naturals or bents, findings showed a positive relationship between the sorbents and the oil 
(Banerjee et al., 2006; Annunciado et al., 2005; Bilba et al., 2007; Ajmal et al., 1998; Choi \& Cloud, 1992; Olga et al., 2015; Sidik et al., 2012).

Likewise, banana trunk fibers (BTF) modified with oleic acid, stearic acid, castor oil, and palm oil were analyzed, and findings were that "BTF treated with oleic acid exhibited the best sorption capacity for engine oil, dissolved organic compounds in weathered oil, and light oil fractions" (Sathasivam \& Haris, 2010). The sorption efficiency and capacity of raw and modified fibers for three types of oil: diesel oil, crude oil and vegetable oil were studied. Accordingly, that the efficiency of fibers to remove different types of oil from artificial saline water was related to sorption time and the system conditions depending on the oil film thickness, temperature, particle size and sorbent dosage (Abdelwahab et al., 2017). However, these studies are still undergoing experimentations and their applicability to larger spill clean-up.

Similarly, outside the natural fibre clean-up materials, Bergaplass and Eriksen (2012) explained various oil spill cleaning methods in use and these included; in-situ burning of oil spill, high-pressure system for on-land clean-up, standard oil boom, foxtail skimmer for oil spill response, and dispersion system mounted on an airplane. In the location under study, most of the participants explained that scooping of the oil from the surface and bury them in a dug pit and in-situ burning are the mostly applied methods. The dispersal method they applied is the local one whereby they dissolve detergents in water and pour the mon the water surface to neutralize the oil coatings so as to allow their fishing boats to move.

\section{Method}

The study was conducted in Ohaji/Egbema and Oguta communities in Imo state Nigeria as there is frequent oil spillages in these communities whose occupation are mainly farming and fishing. The oil spill in these locations occurs both on land and water which pollutes the water making it unsafe for community use while the fishes and aquatics are destroyed. The farmlands are destroyed, leading to little or no yield at all. Mixed method approach was used in data collection; meaning both questionnaires were administered and interview was conducted (Tashakkori \& Teddlie, 1998; Teddlie \& Tashakkori, 2009; Creswell, 2009; Creswell \& Plano-Clark, 2007; Dowding, 2013). The qualitative data for this study is part of the data collected for a larger study on socio-economic impact of oil spill in Ohaji/Egbema and Oguta communities in Imo State. A total of 376 respondents who answered the questionnaires correctly out of 400 questionnaires administered and 13 informants were interviewed. Respondents in this study were chosen conveniently from the population as the inclusion criteria were residency (male and female) in the locations of study within the ages of 18 through 86 and above. A purposive approach was used in selecting informants for the qualitative study. The use of the unstructured interview style helped the informants to open up freely in releasing more supplementary and complementary information that was relevant in the research. This approach was used to select informants with adequate experience, knowledge and willingness to give accurate information on the oil spill in the location of study and descriptive statistics, coding, thematizing used in the data analysis.

The choice of location was because out of the twenty-seven local governments that make up Imo state, oil spill is more pronounced in the Oguta, Ohaji/Egbema and Ngor - Okpuala local communities. The researcher decided to choose two out of the three local communities where oil is drilled and oil spill occurs more frequently. Ohaji/Egbema Local government 
area has a population of 182,538 comprising male 92,604 and Female 90,287 while Oguta Local government Area has a population of 143,008 made up of Male 72,549 and Female 69,791. ((National Population Commission, 2006) and with a projection of $2.5 \%$ population increase annually.

\section{Communities participation in oil spill clean-up in Imo State}

The participation of communities in oil spillage in the location of study has two major perspectives. First, the community see it as a volunteer service to help in cleaning their environment and keep it free from oil, and the second, some participate in the clean-up as a source of employment to generate money for their living expenses since the spill has destroyed their farms, business and sources of revenue. The cash payment to the participants in the clean-up is when the contract for the clean-up is awarded to cleaning companies who then employ some members of the community. The informants in this study emphasize that the oil companies play a warm look attitude in events of oil spill and the communities most times start the clean-up by scooping and burning the oil on the surface and digging pits where the oil was collected and covered with the soil. One of the residents when asked by the researcher on their level of participation during oil spill had this to say:

"Yes, our communities participate in oil spill through the clean-up which is done as voluntary service or paid service. But the clean-up is not every time, most times the spill are not cleaned, the oil are left to sink into the soil and then dry upon the land surface. The community or owners of the farms would then set it on fire to burn the oil and leave the farm fallow for some years praying that the vegetation would grow back but even when the vegetation gets back the crop yield was very poor".

It was also discovered in the study location that the level of participation in event of spill covered identification, implementation, monitoring and evaluation and benefit sharing (Boxill et al., 1997; Cohen \& Uphoff, 1977). These processes were very slow and ineffective as the oil companies may lack the sophisticated equipment for oil spillage detection. Even when the communities inform them of the spillage, the bureaucratic nature in the polity makes actions delayed and such delays lead to greater negative impacts. When spill occurred, the community members living or having activities within the spill location identifies the spill and most cases report to the community heads, the media and government. The community discover where the oil is leaking which they claimed most cases were from the pipelines that are scattered within the residential areas or in their farms and fishing waters. The residents interviewed by the researcher said thus:

"Once the spill is seen, the community head is informed and the youths are mobilized to rush to the scene to ensure that the security of lives is guaranteed because if this is not done, fire might start as people rush and struggle to take advantage of the spill to scoop crude oil into containers for sale. Before the oil company and government security agents are trooped into the place to guard the spill location, the community try to secure the place". 
"Yes, our environment has been polluted and oil is seen everywhere even in hour residential areas. Hard to get good drinking water here as the rivers and streams have been polluted and you see oil on the water surface (oil slick). Even when you try to sink private borehole you discover that the water underneath has mixed with oil. All over, land, sea and air are all polluted and that is why we have various types of illnesses here including stomach ache, headache, skin diseases, respiratory diseases and infections, kidney and lungs diseases and more and more". "We discover the oil spill location seven before the oil workers are brought to try to seal the spot, it takes at times weeks before they could complete the sealing of the spill".

The issue of identification of the leakages is the first role of the communities' participation in event of spillage. Once the spill is identified by either the residents or the oil company, the process of trying to stop the spill (implementation) follows and at times this takes days and weeks before forces are mobilized to control and finally stop the spill actively. The community is not left out in this also, though they lack the high technological equipment to control and stop the spill but they play their little roles in controlling the spill as voluntary or paid labour working with the oil company staff. There have been numerous cases residents got burnt in a bid to either try to stop the spill or steal crude oil in event of spillage. Informants explained that the clean-up in event of oil spill in the location under study is done by the residents manually without adequate equipment and no gloves and protectives wear. Sometimes the oil on the surface was set ablaze to burn for days, thereby contributing to the pollution of the environment. No advanced system of clean-up was done. The communities also involved in the monitoring by visiting the site of spill to see the work done in the clean-up. Most cases the youths, the elders in the communities and the representatives of the traditional rulers dedicate time to monitor the clean-up operation.

A resident questioned on their participation in oil spill clean-up thus said:

"We do participate in the oil clean-up when there is oil spill especially when on our farmlands, we organize community labour to scoop oil from the farm and burn them. Then the farm is left for some number of years to try and get back to farming land again. Environmentally, the oil spill has polluted the whole place. You cannot do anything good on the land. So long as there is oil spillage the land is destroyed. Honestly speaking the management of oil spillage in our communities is very poor. Government and oil companies are not committed to handling the oil spill".

In the location under study, spills occur both on land and on the river, which makes the clean-up operation more cumbersome. Most cases the traditional methods of scooping oil on river surface and in-situ burning of the oil in case of land spillage is adopted. These communities are not professional oil spill cleaners and lack the training, without the use of gadgets and high technological approaches.

\section{Adverse health impacts of oil spill clean-up}

Previous studies have mentioned the effects of oil spill on the communities and participants in the oil spill clean-up, (Zock et al., 2007; Jung et al., 2017; Ha et al., 2013; Choi et al., 2016; 
Gwack et al., 2012; Janjua et al., 2006; Yim et al., 2012; Hong et al., 2014; Cheong et al., 2012). These studies have observed such acute health symptoms on clean-up participants includes neurologic (headache, dizziness, nausea, fatigue, insomnia, hot flushing), respiratory (sore throat, dry mouth, runny nose, cough and sputum), and the dermatological symptoms itching and red skin; ophthalmic symptoms include sore eyes, red eyes, and watery eyes while the general symptoms include back pain and general ache.

In this study, the individuals who participated in the clean-up suffered various symptoms including headache, respiratory disorders, various skin diseases, itching and sore eyes, pains, tiredness and general body weakness. Some also suffered itchy eyes, teary eyes, eye mucus, running nose, poor vision, diarrhea, anxiety, injuries and body pains, bruises, blisters, nausea and vomiting. There were cases of sore feet and pealing of the feet due to non-wearing of protective booths during the clean-up. It was discovered that the peeling of the skin, palms and feet were due to contacts with the oil as many of the participants in the clean-up did not wear hand gloves and adequate body protective clothes and eye covers. The clean-up participants complained that they were treated in a nearby hospital outside the spill area and they paid for the cost of their treatments. Similarly, participants in the cleanup interviewed said they had direct contact of the oil on their legs and some on their hands as they did not wear complete cleaning equipment and all agreed they inhaled the oil mist. There were no medical experts to clean up the participants rather they used soap and water to wash off the oil while few accept reducing chemical agents to remove the oil. The task performed by the clean-up participants and communities during the clean-up involved scooping up oil by the sea with the help of boats, scooping up oil by the land and farmland with containers, distribution of materials used in clean-up, organization of workforce in the clean-up, transportation of fuel/oil through trucks etc., and cleaning of people who participated in the clean-up by washing their hands and feet.

The results of the qualitative interview show that communities in Ohaji/Egbema and Oguta in Imo state Nigeria actively participated in oil spill clean-ups in their localities and at the end of it suffered great socio-economic, psychological and health impacts. Even residents who did not participate in the clean-up suffered some of the symptoms due to the proximity of the spill to their houses, the contaminations of the environment and water they use for their daily activities. The result of the interviews also shows that participants in the spill clean-up were not only doing the mas voluntary humanitarian services but also saw it as a means of earning income. This is similar to the findings of Jung et al., (2017) in the clean-up of the Hebei Spirit spill in South Korea where he posited that many residents participated as paid workers. The only difference between the Hebei clean-up and that of the location under study is the method of clean-up. Also, while the clean-up of the Hebei spill was at the seashore coastal lines, that of location of study was both on land and water (rivers). Similarly, in a study conducted on people that participated in the clean-up of oil spill after seven years showed that they experience persistent alterations or worsening of their hematological, hepatic, pulmonary, and cardiac functions. In addition, these subjects experienced prolonged or worsening illness symptom seven years after their exposure to the oil spill. The cardiac abnormalities that were seen in the initial visit persisted even seven years after the disaster in most of the oil spill clean-up workers (D'Andrea \& Reddy, 2013).

This goes to explain the harmful health effects of oil spill since the harm persists years after and residents in the study area also complained of persistent health problems. The participants in this study did not show nor explained any issues of high or changes in aggressiveness after participation in the clean-up as their only complaint was the 
psychological trauma and other socio-economic impacts. Remembering the spill incidents, the cash and economic crops that were destroyed, the dead fishes at the water shores, animals trapped dead in the oil and other harms caused by the spill continue to cause nightmare to them.

\section{Conclusions and Recommendations}

The study has shown that the people who participated in the clean-up operations suffered various ill-health like cough, vomiting, diarrhea, general pain, running nose, eye irritation, blisters, fever and other symptoms as is the case of other oil spill locations over the globe. The effects of oil spill are devastating and efforts should be made to handle the clean-up quickly and efficiently using professionals and modern technologies. The communities should be trained on how to handle oil clean-up operations using modern gadgets so as to reduce the hazardous impacts of clean-up on the participants.

This paper suggests that since there is existing legislation of oil spill clean-up, the companies whose activities caused the spill should be monitored by the government and made to adhere strictly to the implementation of these legislations. However, to create serious and immediate report of oil spill, the researcher suggests there should be a fixed remunerate on to the community that identifies and notifies the oil spill to the government or the oil companies since the power of money can increase vigilance.

It is also the author's suggestion that highly equipped private oil clean-up companies should be hired in event of oil spill in these Niger Delta communities so as to ensure effective and efficient clean-up operations. Such companies local or international should be made to register with the Federal Government of Nigeria and have their offices located in Nigeria so that once there is an oil spill, such company/companies would be notified and their services hired by the authorities responsible for the clean-up. The government should also make it mandatory on the communities to send their clean-up assessment report to the oil companies and government after the clean-up as this would be like a watchdog on the cleaning companies and the authorities can make policy decisions on the level of work and perfection based on these reports.

This study has examined the reports of the informants and the respondents on the high negative impacts of the frequent oil spill, the conflicts between the communities, the oil companies and government over the years, recommends the setting up of joint-member committee comprising representatives from the major three stakeholders (the oil companies, the government and communities). This joint committee would be meeting regularly to discuss issues emanating from the oil spill and find solutions. Likewise, the problem of the Niger Delta region, oil spill and the socio-economic problems can effectively be solved when experts in the field of community development, sociology, psychology and related disciplines are consulted and utilized in these joint committees as the top-bottom approach currently adopted by the government have not been able to solve these problems over the years. Hence this research, suggests the full adoption of the mixed methods approach as may be directed and monitored by community development experts in handling the issues emanating from oil spills in Imo State. This suggestion is also in line with the views of community development approach for uneducated communities (Isidiho \& Sabran, 2016). 


\section{References}

Abbriano, R.M., Carranza, M.M., Hogle, S.L., Levin, R.A., Netburn, A.N., Seto, K.L., Snyder, S.M. \& Franks, P.J. (2011). Deepwater Horizon oil spill: A review of the planktonic response. Oceanography, 24(3), 294-301.

Abdelwahab, O., Nasr, S.M., \& Thabet, W.M. (2017). Palm fibers and modified palm fibers adsorbents for different oils. Alexandria Engineering Journal, 56(4), 749-755.

Adelana, S.O., Adeosun, T.A., Adesina, A.O., \& Ojuroye, M.O. (2011). Environmental pollution and remediation: challenges and management of oil Spillage in the Nigerian coastal areas. American Journal of Scientific and Industrial Research, 2(6), 834-845.

Ajmal, M., Khan, A.H., Ahmad, S., \& Ahmad, A. (1998). Role of sawdust in the removal of copper (II) from industrial wastes. Water research, 32(10), 3085-3091.

Ajugwo, A.O. (2013). Negative effects of gas flaring: The Nigerian experience. Journal of Environment Pollution and Human Health, 1(1), 6-8.

Amnesty International. (2013). Bad Information: Oil Spill Investigations in the Niger Delta. Retrieved from www.amnesty.org/en/library/asset/AFR44/.../afr440282013en.pdf.

Annunciado, T.R., Sydenstricker, T.H.D., \& Amico, S.C. (2005). Experimental investigation of various vegetable fibers as sorbent materials for oil spills. Marine pollution bulletin, 50(11), 1340-1346.

Asadpour, R., Sapari, N.B., Tuan, Z.Z., Jusoh, H., Riahi, A., \& Uka, O.K. (2013). Application of Sorbent materials in Oil Spill management: A review. Caspian Journal of Applied Sciences Research, 2(2), 4658.

Averett, N. (2016). Louisiana State of Mind: Women's Mental Health after the Deepwater Horizon Oil Spill. Environmental health perspectives, 124(9), A170.

Balena, R. (2015). Priority responses to the 2006 Guimaras oil spill, Philippines: Will history repeat itself?. Ocean \& Coastal Management, 103, 42-55.

Banerjee, S.S., Joshi, M.V., \& Jayaram, R.V. (2006). Treatment of oil spill by sorption technique using fatty acid grafted sawdust. Chemosphere, 64(6), 1026-1031.

Bergaplass, K.T., \& Eriksen, C. (2012). Industrial Opportunities in Oil Spill Response in Norway: An Analysis of the Technological Innovation System of Oil Spill Response. Master's thesis, Institutt for industriell $\emptyset$ konomi og teknologiledelse.

Betinis, K. (2010). The social and economic impact of the Gulf oil spill. World Socialist Website. Retrieved from https://www.wsws.org/en/articles/2010/05/gulf-m24.html.

Biello, D. (2010). Slick Solution: How Microbes Will Clean Up the Deepwater Horizon Oil Spill. Scientific American. Retrieved from http://www.scientificamerican.com/article.cfm?id=how-microbes-clean-upoil-spills.

Bilba, K., Arsene, M.A., \& Ouensanga, A. (2007). Study of banana and coconut fibers: Botanical composition, thermal degradation and textural observations. Bioresource technology, 98(1), 58-68.

Boxill, I., Chambers, C.M., \& Wint, E. (1997). Introduction to social research: With applications to the Caribbean. The University of the West Indies Press: Kingston.

Cheong, H.K., Ha, M., Lee, J.S., Kwon, H., Ha, E.H., Hong, Y.C., Choi, Y., Jeong, W., Hur. J., Kim, E.J., \& Im. H. (2012). Erratum: Hebei Spirit Oil Spill Exposure and Subjective Symptoms in Residents Participating in Clean-Up Activities. Environmental Health and Toxicology, 27.

Choi, H.M., \& Cloud, R.M. (1992). Natural sorbents in oil spill clean-up. Environmental science \& technology, 26(4), 772-776.

Choi, K.H., Lim, M.H., Ha, M., Sohn, J.N., Kang, J.W., Choi, Y.H., \& Cheong, H.K. (2016). Psychological vulnerability of residents of Communities affected by the Hebei Spirit Oil spill. Disaster Med Public Health Prep, 10(1), 51-58.

Cohen, J.M., and Uphoff T.N. (1977). Rural Development Participation: Concept and Measures for Project Design, Implementation and Evaluation. Cornell University.

Creswell, J. \& Plano-Clark, V. (2007). Designing and conducting mixed methods research. Sage Publications.

Creswell, J. W. (2009). Research design: Qualitative and mixed methods approaches. Sage Publications.

D'Andrea, M.A., \& Reddy, G.K. (2013). Health consequences among subjects involved in Gulf oil spill cleanup activities. The American journal of medicine, 126(11), 966-974.

Di Natale, M. (2010). The economic impact of the gulf oil spill: The oil leak and drilling moratorium could cost Gulf Coast economies tens of thousands of jobs. Retrieved from https://www.economy.com/dismal/analysis/free/191641.

Dowding, D. (2013). Best Practices for Mixed Methods Research in the Health Sciences John W. Creswell, Ann Carroll Klassen, Vicki L. Plano Clark, Katherine Clegg Smith for the Office of Behavioral and Social Sciences Research; Qualitative Methods Overview Jo Moriarty. Qualitative Social Work, 12(4), 541545. http://doi.org/10.1177/1473325013493540a 
Egwu, S.A. (2012). Oil spill control and management. Petroleum Technology Development Journal, 19(3), 457478.

Epstein, P.R., \& Selber, J.B. (2002). A life cycle analysis of its health and environmental impacts. The Center for Health and the Global Environment. Harvard Medial School, EUA, Marzo: Boston.

Etkin, D.S. (2001). Analysis of oil spill trends in the United States and worldwide. In International oil spill conference, 2001(2), 1297-1299.

Etkin, D.S., McCay, D.F., Rowe, J., \& Pilkey-Jarvis, L. (2005). Modeling impacts of response method and capability on oil spill costs and damages for Washington State spill scenarios. In International Oil Spill Conference, 2005(1), 467-473.

Eykelbosh, A.J. (2014). Short-and long-term health impacts of marine and terrestrial oil spills. Vancouver Coastal Health. Retrieved from www.vch.ca/media/VCH-health-impacts-oil-spill.pdf.

Gill, D.A. (2007). Technological Disaster, Resource Loss and Long-Term Social Change in a Subarctic Community: Exxon Valdez Oil Spill Impacts on Alaska Natives and Commercial Fishermen in Cordova, Alaska-2001-2006. National Science Foundation award\# 0082405. Societal Risk Unit. Social Science Research Center, Mississippi State University.

Gill, D.A., \& Picou, J.S. (1997). The day the water died: cultural impacts of the Exxon Valdez oil spill. In Picou, J.S., Gill, D.A., Cohen, M. (Eds), The Exxon Valdez disaster: readings on a modern social problem (pp. 167-191). Dubuque, Kendall Hunt.

Gill, D.A., \& Picou, J.S. (1998). Technological disaster and chronic community stress. Society \& natural resources, $11(8), 795-815$.

Gill, D.A., \& Picou, J.S. (2001). The day the water died: The Exxon Valdez disaster and indigenous culture. Modern American Disasters, 277-301.

Gill, D.A., Picou, J.S., \& Ritchie, L.A. (2012). The Exxon Valdez and BP oil spills: A comparison of initial social and psychological impacts. American Behavioral Scientist, 56(1), 3-23.

Gill, D.A., Picou, J.S., \& Ritchie, L.A. (2014). Twenty-four years of social science research on the Exxon Valdez oil spill: sociocultural and psychosocial impacts in a commercial fishing community. In International Oil Spill Conference Proceedings, 2014(1), 80-92.

Gutierrez, T. (2011). Identifying polycyclic aromatic hydrocarbon-degrading bacteria in oil-contaminated surface waters at Deepwater Horizon by cultivation, stable isotope probing and pyrosequencing. Reviews in Environmental Science and Bio/technology, 10, 301305. http://dx.doi.org/10.1007/s11157-011-9252-9

Gwack, J., Lee, J.H., Kang, Y.A., Chang, K.J., Lee, M.S., \& Hong, J.Y. (2012). Acute health effects among military personnel participating in the clean-up of the Hebei spirit oil spill, 2007, in Taean county, Korea. Osong Public Health and Research Perspectives, 3(4), 206-212.

Ha, M., Kwon, H., Cheong, H.K., Lim, S., Yoo, S.J., Kim, E.J., Park, S.G., Lee, J., \& Chung, B.C. (2012). Urinary metabolites before and after cleanup and subjective symptoms in volunteer participants in cleanup of the Hebei Spirit oil spill. Science of the total environment, 429, 167-173.

Hansel, T.C., Osofsky, H.J., Osofsky, J.D., \& Speier, A. (2015). Longer-term mental and behavioral health effects of the Deepwater Horizon Gulf oil spill. Journal of Marine Science and Engineering, 3(4), 1260-1271.

Hazen, T.C., Dubinsky, E.A., DeSantis, T.Z., Andersen, G.L., Piceno, Y.M., Singh, N., Jansson, J.K., Probst, A., Borglin, S.E., Fortney, J.L., Stringfellow, W.T., Bill, M., Conrad, M.E., Tom, L.M., Chavarria, K.L., Alusi, T.R., Lamandella, R., Joyner, D.C., Spier, C., Baelum, J., Auer, M., Zemla, M.L., Chakraborty, R., Sonnenthal, E.L., D’haeseleeer, P., Holman, H.N., Osman, S., Lu, Z., Nostrand, J.D.V., Deng, Y., Zhou, J., \& Mason O.U. (2010). Deep-sea oil plume enriches indigenous oildegrading bacteria. Science, 330(6001), 204-208.

Hong, S., Khim, J.S., Ryu, J., Kang, S.G., Shim, W.J., \& Yim, U.H. (2014). Environmental and ecological effects and recoveries after five years of the Hebei Spirit oil spill, Taean, Korea. Ocean \& coastal management, 102, 522-532.

Horowitz, M., Wilner, N., \& Alvarez, W. (1979). Impact of Event Scale: A measure of subjective stress. Psychosomatic medicine, 41(3), 209-218.

Idris, J., Eyu, G.D., Mansor, A.M., Ahmad, Z., \& Chukwuekezie, C.S. (2014). A preliminary study of biodegradable waste as sorbent material for oil-spill cleanup. The Scientific World Journal, 2014, 1-5. http://dx.doi.org/10.1155/2014/638687.

Isidiho, A.O., \& Sabran, M.S.B. (2016). Evaluating the top-bottom and bottom-up community development approaches: Mixed method approach as alternative for rural un-educated communities in developing countries. Mediterranean Journal of Social Sciences, 7(4), 266-273.

Janjua, N.Z., Kasi, P.M., Nawaz, H., Farooqui, S.Z., Khuwaja, U.B., Jafri, S.N., Lutfi, S.A., Kadir, M.M., \& Sathiakumar, N. (2006). Acute health effects of the Tasman Spirit oil spill on residents of Karachi, Pakistan. BMC Public Health, 6(1), 84. 
Jones, C. (2011). Tourism returning a year after the Gulf oil spill. Retrieved from http://usatoday30.usatoday.com/news/nation/2011-04-20-tourism-rebounds-gulf-.htm.

Jung, D., Kim, J.A., Park, M.S., Yim, U.H., \& Choi, K. (2017). Human health and ecological assessment programs for Hebei Spirit oil spill accident of 2007: Status, lessons, and future challenges. Chemosphere, 173, 180-189.

Kate, A. (2011). Royal Dutch Shell and its sustainability troubles. Background report to the Erratum of Shell's Annual Report 2010. 1-71. Retrieved from https://www.foei.org/wp-content/uploads/2011/05/Shellbackground-report.pdf

Kwok, R.K., Engel, L.S., Miller, A.K., Blair, A., Curry, M.D., Jackson, W.B., Stewart, P.A., Stenzel, M.R., Birnbaum, L.S., Sandler, D.P., \& GuLF STUDY Research Team. (2017). The GuLF STUDY: a prospective study of persons involved in the Deepwater Horizon oil spill response and cleanup. Environmental health perspectives, 125(4), 570-578.

Lee, J., Rehner, T., Choi, H., Bougere, A., \& Osowski, T. (2016). The Deepwater Horizon oil spill and factors associated with depressive symptoms among residents of the Mississippi Gulf Coast. Disaster Prevention and Management, 25(4), 534-549.

Morita, A., Kusaka, Y., Deguchi, Y., Moriuchi, A., Nakanaga, Y., Iki, M., Miyazaki, S., \& Kawahara, K. (1999). Acute health problems among the people engaged in the cleanup of the Nakhodka oil spill. Environmental Research, 81(3), 185-194.

Muizis, A. (2013). Evaluation of the Methods for the Oil Spill Response in the Offshore Arctic Region. Thesis Submitted at Hel sinki Metropolia University of Applied Sciences.

National Oceanographic and Atmospheric Administration. (2010). Oil and sea turtles: biology, planning, and response. US National Oceanic and Atmospheric Administration, Office of Response and Restoration. Retrieved from https://response.restoration.noaa.gov/sites/default/files/Oil_Sea_Turtles.pdf

National Population Commission. (2006). National population and housing census. Abuja, Federal Government of Nigeria.

Nriagu, J.O. (2011). Oil industry and the health of communities in the Niger Delta of Nigeria. Encycl. Environ. Health, 4, 558-567.

Olga, R., Viktor, R., Alexander, I., Zinnur, S., \& Alexandra, P. (2015). Adsorption of hydrocarbons using natural adsorbents of plant origin. Procedia Chemistry, 15, 231-236. 10.1016/j.proche.2015.10.037

Palinkas, L.A., Petterson, J.S., Russell, J., \& Downs, M.A. (1993). Community patterns of psychiatric disorders after the Exxon Valdez oil spill. The American Journal of Psychiatry, 150(10), 1517-1523. https://doi.org/10.1176/ajp.150.10.1517

Peres, C.A., Emilio, T., Schietti, J., Desmoulière, S.J., \& Levi, T. (2016). Dispersal limitation induces long-term biomass collapse in overhunted Amazonian forests. Proceedings of the National Academy of Sciences, 113(4), 892-897. 10.1073/pnas.1516525113

Picou, J.S. (1996). Toxins in the environment, damage to the community: sociology and the toxic tort. Witnessing for sociology: Sociologists in court, 211, 212-224.

Picou, J.S., \& Gill, D.A. (1997). Commercial fishers and stress: psychological impacts of the Exxon Valdez oil spill. The Exxon Valdez disaster: Readings on a modern social problem, 211-236.

Picou, J.S., \& Gill, D.A. (1996). The Exxon Valdez oil spill and chronic psychological stress. American Fisheries Society Symposium, 18, 879-893.

Picou, J.S., \& Arata, C. (1997). Chronic impacts of the Exxon Valdez oil spill: Resource loss and commercial fishers. Coping with Technological Disasters, 1997, J2-J43.

Pigrau, A. (2012). The Texaco-Chevron Case in Ecuador. Ejolt Factsheet, 42, 12.

Ramseur, J.L. (2010). Oil spills in US coastal waters: background, governance, and issues for congress. Diane Publishing.

Rim-Rukeh, A. (2015). Oil spill management in Nigeria: SWOT analysis of the joint investigation visit (JIV) process. Journal of Environmental Protection, 6(3), 259.

Ritchie, L.A., Gill, D.A., \& Farnham, C.N. (2013). Recreancy revisited: Beliefs about institutional failure following the Exxon Valdez oil spill. Society \& Natural Resources, 26(6), 655-671.

Rung, A.L., Gaston, S., Oral, E., Robinson, W.T., Fontham, E., Harrington, D.J., Trapido, E., \& Peters, E.S. (2016). Depression, mental distress, and domestic conflict among Louisiana women exposed to the Deepwater Horizon oil spill in the WaTCH study. Environmental health perspectives, 124(9), 14291435.

Sathasivam, K., \& Haris, M.R.H.M. (2010). Adsorption kinetics and capacity of fatty acid-modified banana trunk fibers for oil in water. Water, Air, \& Soil Pollution, 213(1-4), 413-423.

Sholeye, O., Salako, A., \& Ayankoya, S. (2012). Oil spills and community health: Implications for resource limited settings. Journal of Toxicology and Environmental Health Sciences, 4(9), 145-150. 
Shultz, J.M., Walsh, L., Garfin, D.R., Wilson, F.E., \& Neria, Y. (2015). The 2010 Deepwater Horizon oil spill: the trauma signature of an ecological disaster. The journal of behavioral health services \& research, 42(1), 58-76.

Sidik, S. M., Jalil, A.A., Triwahyono, S., Adam, S.H., Satar, M.A.H., \& Hameed, B.H. (2012). Modified oil palm leaves adsorbent with enhanced hydrophobicity for crude oil removal. Chemical Engineering Journal, 203, 9-18. 10.1016/j.cej.2012.06.132

Solomon, G.M., \& Janssen, S. (2010). Health effects of the Gulf oil spill. Jama, 304(10), 1118-1119.

Stanbury, M., Hekman, K., Wells, E., Miller, C., Smolinske, S., \& Rutherford, J. (2010). Acute Health Effects of the Enbridge Oil Spill. Lansing, Michigan, 1-23.

Steiner, R. (2010). Double standard: Shell Practices in Nigeria Compared with International Standards to Prevent and Control Pipeline Oil Spills and the Deepwater Horizon Oil Spill. This report is written on behalf of: Friends of the Earth Netherlands. Retrieved from http://oasisearth.com/Resources/Milieudefensie\%20rapport\%20Shell\%20Double\%20Standard\%20L\% $2010-50-4435 \% 20$ LR.pdf

Tashakkori, A., Teddlie, C., \& Teddlie, C.B. (1998). Mixed methodology: Combining qualitative and quantitative approaches (Vol. 46). Sage Publication.

Teddlie, C., \& Tashakkori, A. (2009). Foundations of mixed methods research: Integrating quantitative and qualitative approaches in the social and behavioral sciences. Sage.

Turan, M. (2009). Turkey's Oil Spill Response Policy: Influences and Implementation. The United NationsNippon Foundation Fellowship Programme 2008-2009. Retrieved from https://www.un.org/depts/los/nippon/unnff_programme_home/fellows_pages/fellows_papers/turan_08 09_turkey.pdf

United Nations Environment Programme. (2011). UNEP Environmental Assessment of Ogoniland. United Nations Environment Programme: Kenya

White, I. C. \& Molloy F. C. (2003). Factors that determine the cost of oil spills. International oil spill conference, 2003(1), 1225-1229.

Whitehead, A., Dubansky, B., Bodinier, C., Garcia, T.I., Miles, S., Pilley, C., Raghunathan, V., Roach, J.L., Walker, N., Walter, R.B., Rice, C.D., \& Galvez, F. (2012). Genomic and physiological footprint of the Deepwater Horizon oil spill on resident marsh fishes. Proceedings of the National Academy of Sciences, 109(50), 20298-20302.

Yim, U.H., Kim, M., Ha, S.Y., Kim, S., \& Shim, W.J. (2012). Oil spill environmental forensics: the Hebei Spirit oil spill case. Environ. Sci. Technol. 46(12), 6431-6437.

Zock, J.P., Rodríguez-Trigo, G., Pozo-Rodríguez, F., Barberà, J.A., Bouso, L., Torralba, Y., Anto, J.M., Gomez, F.P., Fuster, C., Verea, H., \& SEPAR-Prestige Study Group*. (2007). Prolonged respiratory symptoms in clean-up workers of the prestige oil spill. American journal of respiratory and critical care medicine, 176(6), 610-616.

Zock, J.P., Rodríguez-Trigo, G., Rodríguez-Rodríguez, E., Espinosa, A., Pozo-Rodríguez, F., Gómez, F., Fuster, C., Castano-Vinyals, G., Anto, J.M., \& Barberà, J.A. (2012). Persistent respiratory symptoms in cleanup workers 5 years after the Prestige oil spill. Occupational and environmental medicine, 69(7), 508513. 10.1136/oemed-2011-100614 